\title{
Cancer care network: Structure analysis of enabled services
}

\author{
Marisa Riscalla Madi ${ }^{1 *}$, Giovanni Guido Cerri ${ }^{1}$ \\ ${ }^{1}$ Instituto de Radiologia do Hospital das Clínicas da Faculdade de Medicina da Universidade de São Paulo, São Paulo, SP, Brazil
}

Study conducted at Instituto de Radiologia do Hospital das Clínicas da Faculdade de Medicina da Universidade de São Paulo, São Paulo, SP, Brazil

Article received: 6/6/2017 Accepted for publication: 6/11/2017

*Correspondence: Instituto de Radiologia - HC-FMUSP Address: Travessa da Rua Dr. Ovídio Pires de Campos, 75 São Paulo, SP - Brazil Postal code: 05403-010 marisa.madi@hc.fm.usp.br

\section{SUMMARY}

Introduction: Cancer has now become part of the agenda of health managers, prompting them to consider new models of system organization.

Objective: To study the cancer care network of the Brazilian public health system (SUS, in the Portuguese acronym) in the state of São Paulo by analyzing the structure of the installed and enabled network for treatment and its characteristics.

Method: A single, integrated case study. We used secondary data from the following sources: Datasus, Inca, RHC and CNES, and primary data from official documents from the Reference Committee on Oncology of the State of Sao Paulo. We used the official guidelines to able services from the National Health Department to make comparison.

Results: According to the CNES, in April, 2013 there were 72 cancer care services authorized by SUS in the state of Sao Paulo. Using the population criterion, the state had one service enabled for every 581,961 inhabitants, in an unequal distribution throughout the 17 health care regions. In terms of available structure and services, $80 \%$ of the hospitals were compliant for cancer surgery, $31 \%$ for chemotherapy and $74 \%$ for radiotherapy. In terms of minimum production, only $13 \%$ of hospitals were compliant with cancer surgery, $42 \%$ with chemotherapy and $14 \%$ with radiotherapy. Conclusion: The installed network proved to have sufficient size and structure to meet the demand from new cancer cases. However, there were both regional differences, as well as a wide variation in productivity between services, which probably had an impact on patient access.

Keywords: medical oncology, health services, health policy, planning and management.

\section{INTRODUCTION}

The WHO's forecast is that chronic conditions will account for $78 \%$ of the global disease burden by 2020 . However, health systems and services are still organized to attend to acute conditions, with a focus on curing patients and offering services within hospitals - a model that no longer meets current needs. ${ }^{1}$ The main challenge is to provide continuous patient care that uses different units in the system, at different levels of complexity and over a long period of time. A large part of this care depends on the decisions and attitudes of the patients themselves, and the structural and cultural conditions of the community of which they are a part. ${ }^{2}$

To meet this challenge, a care model for chronic conditions ${ }^{3}$ has been proposed, alongside the strategy of organizing health care networks. ${ }^{4}$ In Brazil, since its conception, the Brazilian public health system (SUS, in the Portuguese acronym) has been organized based on regions and networks. ${ }^{5}$ More recently, the Mendes concept served as basis for the guidelines of organization of the SUS into Health Care Networks. ${ }^{6}$

According to this concept, the state of São Paulo was divided into 17 Regional Health Care Networks (RRAS), each composed of health services of different technological densities and support systems to guarantee the integrality of care. ${ }^{7}$ It is within these territories that the Thematic Networks must be organized, including the Oncology Network, which is the subject of our study.

In the period from 2000 to 2009 , there was a gradual increase in cancer morbidity in both women and men, with almost half of cases (47.8\%) reaching services in advanced stages of the disease (stages III and IV), with oncology accounting for $0.5 \%$ of procedures and $9.1 \%$ of expenditures, meaning a $111 \%$ increase. ${ }^{8}$ In addition, cancer 
mortality increased from third to second position at a percentage of 15 to $18 \%{ }^{9}$

It is in this context that the activities of the Cancer Institute of the State of São Paulo (Icesp) began on May 8, 2008 with the purpose of providing comprehensive care for adult cancer patients at all stages of their treatment and in all of their needs. ${ }^{10}$ In almost three years of operation, the Icesp has established itself as the technical benchmark in oncology for the State Health Department $(\mathrm{SES})^{11}$ and began coordinating the Reference Committee on Oncology of the State of São Paulo, created by the SES to implement the Oncology Healthcare Plan. ${ }^{12}$

In the perspective of patient care, the guidelines in this Plan include actions proposing to scale the network and its regional needs, as well as implementing tools to qualify it. ${ }^{13}$ Because it is a highly complex service, the challenge is to balance the concentration of services in high technology and specialized services, which have gained efficiency and quality in the volume of care, with ease of access by patients. ${ }^{6}$

For the provision of cancer care under the SUS, there is a need for specific authorization determined by technical criteria included in Ministerial Orders. ${ }^{14}$ Since the first Ordinance in 1993, there has been a gradual orientation towards full care of cancer patients in the same service, the introduction of a minimum volume of procedures and, with the most recent ordinance in 2014, the need for services is integrated into the healthcare networks. ${ }^{15}$

Therefore, based on the evaluation of the network of establishments qualified for cancer care in the SUS in 2013, we sought to contribute to the understanding of the status of the network installed for cancer treatment. This was done against the criteria defined by the SUS, in terms of the structure and minimum services available for the performance of cancer surgeries, chemotherapy and radiotherapy procedures in relation to the minimum annual production expected for these treatment modalities.

\section{Method}

This is a unique integrated descriptive case study of the cancer network in the state of São Paulo from 2011 to 2014. Our study was approved by the Research Ethics Committee of the University of São Paulo Medical School on April 8, 2015, under Research Protocol no. 069/15.

Secondary data were obtained from the official SUS database (Datasus 2012, CNES 2013), the Cancer Hospital Registry databases (Inca 2013 estimate, RHC/SP, 2012), SES official documents (Production Report 2013 of the State Health Department - multiple and sequential surgeries in oncology, and the Oncology Reference Commit- tee of the State of São Paulo (Visits Report of the Hebe Camargo Network to Combat Cancer 2014).

The primary data was collected from the Operational and Installed Capacity Survey Form of the Oncology Network of the State of São Paulo in 2013, prepared by the Reference Committee on Oncology of the State of São Paulo and applied by teams composed of professionals from the SES technical staff and the Executive Office of the Reference Committee on Oncology, in a process involving visits to the 72 approved units during the period from May to November, 2013.

The services were classified as conforming or nonconforming according to whether or not they complied with the parameters of MS/SAS Ordinance no. 140 of 2014 for the three treatment modalities, namely cancer surgeries, chemotherapy sessions and radiotherapy fields. They were evaluated according to the structure and services required, according to the type of authorization and the minimum volume of annual procedures.

For the analysis and interpretation of the data we used descriptive statistics with absolute numbers, percentages and medians, calculated using spreadsheets and formulas in Microsoft ${ }^{\circledR}$ Excel $^{\circledR} 2013$.

\section{ResULtS}

In 2013, the state of São Paulo had a network of 72 hospitals qualified by the Ministry of Health for cancer care by the SUS. Sixteen of these were Oncology High Complexity Care Centers (CACONs), 51 were Oncology High Complexity Assistance Units (UNACONs) and five were General Hospitals with cancer surgery. Only 12 were specialized in oncology and 36 had a radiotherapy service. Most were general, private non-profit, large and special size hospitals with teaching activities. General Hospitals with cancer surgery did not fit this profile. They were all State public hospitals, and the five hospitals specialized in pediatric cancer care were small-sized and did not provide teaching activities.

A little more than half of the hospitals stated that they provided supplementary health care in a proportion ranging from 1 to $38 \%$. Forty-one (41) of them still kept patient records/charts on paper.

There were no more isolated chemotherapy and radiotherapy services, and all the qualified establishments were hospitals. According to the population criterion, the State had one qualified service for every 581,961 inhabitants, distributed unequally among the 17 RRAS, varying from one service for 269,373 inhabitants to one service for $2,717,672$ inhabitants. In two regions there were no qualified services of any type, and in one region there was only one general hospital that provided cancer surgery. To achieve the proportion recommended by the Ministry of 
Health, it would be necessary to qualify 12 more units, and all regions with over 500,000 inhabitants would be expected to have at least one qualified service. If we consider the supplementary health coverage to be $45.4 \%$ in the state, the installed network would have five more units than necessary. Under the criterion of 1 unit for every 900 new cases, it would be necessary to qualify 44 more hospitals, or 21 if we consider the supplementary health coverage plus a migration of $20 \%$ of the cases to chemotherapy and radiotherapy procedures. Also under this criterion, there should be at least one unit per region, since the lowest estimate was 1,888 new cases in RRAS 3 (Table 1).

Only two of the 72 qualified establishments did not submit the completed form and therefore were excluded from the analyses that used this information. One of these was a CACON with pediatric cancer care, a specialized, largescale establishment under municipal management. The other is a CACON, a general unit of special size, under State management. Both are private non-profit institutions, with teaching activities and are located in the city of São Paulo.

One of the establishments classified as a CACON with pediatric cancer care was considered as providing exclusive pediatric cancer care, a situation verified during the visit and not yet updated in the CNES. After 2012, adult cancer treatment was transferred to another institution, included in the sample. Therefore, five of the total of 70 establishments were considered as providing exclusive pediatric cancer care.

The data relating to the analyses presented below comprise Tables 2 and 3 .

\section{Cancer surgeries}

In relation to the structure and services available for cancer surgeries, 56 of the 70 establishments (excluding

\section{TABLE 1 Distribution of establishments qualified in oncology according to RRAS, 2013.}

\begin{tabular}{|c|c|c|c|c|c|c|c|c|c|}
\hline \multirow[t]{2}{*}{ RRAS } & \multirow[t]{2}{*}{$\begin{array}{l}\text { No. of } \\
\text { cities }\end{array}$} & \multirow[t]{2}{*}{$\begin{array}{l}\text { Total } \\
\text { population }\end{array}$} & \multirow[t]{2}{*}{$\begin{array}{l}\text { New cancer } \\
\text { cases (except } \\
\text { non-melanoma } \\
\text { skin cancer) }\end{array}$} & \multicolumn{2}{|c|}{$\begin{array}{l}\text { Number of expected } \\
\text { establishments }\end{array}$} & \multicolumn{2}{|c|}{$\begin{array}{l}\text { Considering } \\
\text { complementary } \\
\text { health coverage } \\
\text { ( } 20 \% \text { discount) }\end{array}$} & \multirow[t]{2}{*}{$\begin{array}{l}\text { No. of } \\
\text { qualified } \\
\text { establish- } \\
\text { ments }\end{array}$} & \multirow[t]{2}{*}{$\begin{array}{l}\text { Establishments/ } \\
\text { inhabitants } \\
(1 \text { to } 500,000)\end{array}$} \\
\hline & & & & $\begin{array}{l}\text { Per } \\
\text { inhabitant }\end{array}$ & $\begin{array}{l}\text { Per new } \\
\text { case }\end{array}$ & $\begin{array}{l}\text { Per } \\
\text { inhabitant }\end{array}$ & $\begin{array}{l}\text { Per new } \\
\text { case }\end{array}$ & & \\
\hline 1 & 7 & $2,581,544$ & 6,275 & 5 & 7 & 4 & 6 & 6 & 430,257 \\
\hline 2 & 11 & $2,717,672$ & 6,608 & 5 & 7 & 4 & 6 & 1 & $2,717,672$ \\
\hline 3 & 5 & 531,829 & 1,296 & 1 & 1 & 1 & 1 & 0 & - \\
\hline 4 & 8 & $1,013,390$ & 2,463 & 2 & 3 & 2 & 2 & 1 & $1,013,390$ \\
\hline 5 & 7 & $1,735,470$ & 4,215 & 3 & 5 & 3 & 4 & 0 & - \\
\hline 6 & 1 & $11,376,685$ & 31,207 & 23 & 35 & 18 & 28 & 17 & 669,217 \\
\hline 7 & 24 & $1,966,489$ & 4,777 & 4 & 5 & 3 & 4 & 5 & 393,298 \\
\hline 8 & 48 & $2,284,897$ & 5,563 & 5 & 6 & 4 & 5 & 2 & $1,142,449$ \\
\hline 9 & 68 & $1,648,443$ & 4,014 & 3 & 4 & 3 & 4 & 4 & 412,111 \\
\hline 10 & 62 & $1,077,491$ & 2,612 & 2 & 3 & 2 & 2 & 4 & 269,373 \\
\hline 11 & 45 & 728,122 & 1,773 & 1 & 2 & 1 & 2 & 2 & 364,061 \\
\hline 12 & 142 & $2,222,578$ & 5,408 & 4 & 6 & 4 & 5 & 4 & 555,645 \\
\hline 13 & 90 & $2,006,684$ & 8,184 & 4 & 9 & 3 & 7 & 7 & 286,669 \\
\hline 14 & 26 & $2,794,360$ & 2,622 & 6 & 3 & 4 & 2 & 5 & 558,872 \\
\hline 15 & 42 & $3,755,762$ & 9,163 & 8 & 10 & 6 & 8 & 6 & 625,960 \\
\hline 16 & 20 & $1,154,045$ & 2,778 & 2 & 3 & 2 & 2 & 2 & 577,023 \\
\hline 17 & 39 & $2,305,758$ & 5,611 & 5 & 6 & 4 & 5 & 6 & 384,293 \\
\hline Total & 645 & $41,901,219$ & 104,569 & 84 & 116 & 67 & 93 & 72 & 581,961 \\
\hline
\end{tabular}

Mun.: municipalities/cities; No.: number; Min.: minimum; Max.: maximum; pop.: population; estab.: establishments;

Source: Datasus E IBGE, 2012; CNES, 2013; Ordinance SASo/MS No. 140; Inca Estimate, 2012. 
the two that did not send the form) were conforming and 14 were nonconforming, yielding a $20 \%$ rate of nonconformity. The main reasons for nonconformity occurred in UNACONs and General Hospitals with Cancer Surgery and were due to the lack of surgical teams, namely surgical oncology (12 times), general surgery and/or coloproctology (five times), gynecology and/or mastology (five times) and urology (two times). The five establishments qualified as General Hospital with cancer surgery (100\%) were also classified as nonconforming due to the lack of connection to a CACON or UNACON.

TABLE 2 Difference between the number of procedures expected and performed in number of cancer surgeries, chemotherapy sessions and radiotherapy fields, 2013.

\begin{tabular}{|c|c|c|c|c|c|c|c|}
\hline & & $\% \mathrm{NC}$ & $\begin{array}{l}\text { Expected } \\
\text { production }\end{array}$ & Production & $\begin{array}{l}\text { Expected difference, } \\
\text { production }\end{array}$ & $\begin{array}{l}\% \text { production of } \\
\text { that expected }\end{array}$ & $\begin{array}{l}\text { Variation in number } \\
\text { and percentage }\end{array}$ \\
\hline \multirow{12}{*}{ 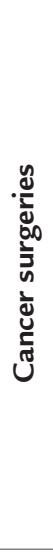 } & CACON & $80 \%$ & 32,500 & 25,229 & 7,271 & $78 \%$ & 2,282 to $+2,043$ \\
\hline & & & & & & & (12\% to $205 \%)$ \\
\hline & UNACON & $82 \%$ & 18,200 & 12,160 & 5,040 & $72 \%$ & 641 to $+1,288$ \\
\hline & & & & & & & ( $1 \%$ to $298 \%)$ \\
\hline & UNACON with & $95 \%$ & 21,450 & 10,041 & 11,409 & $47 \%$ & 1,370 to +337 \\
\hline & radiotherapy & & & & & & (1\% to $117 \%)$ \\
\hline & UNACON exclusive & NA & NA & NA & NA & NA & NA \\
\hline & pediatric cancer care & & & & & & \\
\hline & General Hospital with & $100 \%$ & 3,250 & 930 & 2,320 & $29 \%$ & 600 to 352 \\
\hline & cancer surgery & & & & & & ( $8 \%$ to $46 \%)$ \\
\hline & Total surgeries & $87 \%$ & 75,400 & 49,360 & 26,040 & $65 \%$ & 2,282 to $+2,043$ \\
\hline & & & & & & & $(1 \%$ to $298 \%)$ \\
\hline \multirow{12}{*}{ 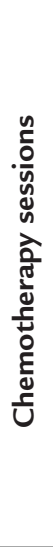 } & CACON & $53 \%$ & 265,000 & 349,937 & 84,937 more & $132 \%$ & 15,761 to $+33,698$ \\
\hline & & & & & & & (26\% to $264 \%)$ \\
\hline & UNACON & $64 \%$ & 148,400 & 202,981 & 54,581 more & $137 \%$ & 5,300 to $+41,284$ \\
\hline & & & & & & & (0\% to $879 \%)$ \\
\hline & UNACON with & $53 \%$ & 174,900 & 168,326 & 6,574 & $96 \%$ & 11,408 to $+13,675$ \\
\hline & radiotherapy & & & & & & $(0 \%$ to $338 \%)$ \\
\hline & UNACON exclusive & NA & 0 & 3,986 & NA & NA & NA \\
\hline & pediatric cancer care & & & & & & \\
\hline & General Hospital with & NA & NA & NA & NA & NA & NA \\
\hline & cancer surgery & & & & & & \\
\hline & Total chemotherapy & $58 \%$ & 588,300 & 725,230 & 136,930 more & $123 \%$ & 15,761 more 41,284 \\
\hline & & & & & & & $(0 \%$ to $879 \%)$ \\
\hline \multirow{10}{*}{ 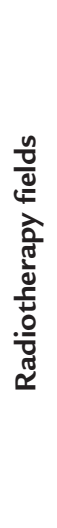 } & CACON & $75 \%$ & $2,279,000$ & $1,658,292$ & 620,708 & $73 \%$ & 153,141 to $+163,785$ \\
\hline & & & & & & & (11\% to $227 \%)$ \\
\hline & UNACON & NA & NA & NA & NA & NA & NA \\
\hline & UNACON with & $95 \%$ & $1,419,000$ & 765,092 & 653,908 & $54 \%$ & 96,187 to $+30,387$ \\
\hline & radiotherapy & & & & & & $(0 \%$ to $171 \%)$ \\
\hline & UNACON exclusive & $100 \%$ & 172,000 & 91,533 & 80,467 & $53 \%$ & 80,467 \\
\hline & pediatric cancer care & & & & & & $(53 \%)$ \\
\hline & $\begin{array}{l}\text { General Hospital with } \\
\text { cancer surgery }\end{array}$ & NA & NA & NA & NA & NA & NA \\
\hline & Total radiotherapy & $86 \%$ & $3,870,000$ & $2,514,917$ & $1,355,083$ & $65 \%$ & 153,141 to $+163,785$ \\
\hline & & & & & & & ( $11 \%$ to $227 \%)$ \\
\hline
\end{tabular}

Source: Installed Capacity Form of the RHCCC 2013, Ordinance SAS/MS No. 140 - 2014, Production Report SES/SP - 2013 - multiple and sequential oncologic surgeries, Datasus, 2013. 
TABLE 3 Percentage of conforming and nonconforming establishments in structure and services available, and minimum annual production in cancer surgeries, chemotherapy sessions and radiotherapy fields, according to qualification characteristics, 2013.

\section{Conformity CACON UNACON UNACON with radiotherapy}

UNACON
exclusive pediatric
cancer care

General

Total

cancer care

Hospital with

cancer surgery

\begin{tabular}{|c|c|c|c|c|c|c|c|c|}
\hline \multirow{7}{*}{ 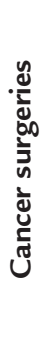 } & \multirow{3}{*}{$\begin{array}{l}\text { Structure and } \\
\text { available services }\end{array}$} & $C$ & 14 & 23 & 15 & 4 & 0 & 56 \\
\hline & & $N C$ & 0 & 5 & 4 & 0 & 5 & 14 \\
\hline & & $\% \mathrm{NC}$ & $0 \%$ & $18 \%$ & $21 \%$ & $0 \%$ & $100 \%$ & $20 \%$ \\
\hline & \multirow{4}{*}{$\begin{array}{l}\text { Annual minimum } \\
\text { production }\end{array}$} & $C$ & 3 & 5 & 1 & 0 & 0 & 9 \\
\hline & & NC & 12 & 23 & 18 & 0 & 5 & 58 \\
\hline & & NA & 1 & 0 & 0 & 4 & 0 & 5 \\
\hline & & $\% \mathrm{NC}$ & $80 \%$ & $82 \%$ & $95 \%$ & $0 \%$ & $100 \%$ & $87 \%$ \\
\hline \multirow{8}{*}{ 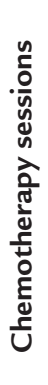 } & \multirow{4}{*}{$\begin{array}{l}\text { Structure and } \\
\text { available services }\end{array}$} & $C$ & 5 & 5 & 7 & 3 & 0 & 20 \\
\hline & & $N C$ & 9 & 23 & 12 & 1 & 0 & 45 \\
\hline & & NA & 0 & 0 & 0 & 0 & 5 & 5 \\
\hline & & $\% \mathrm{NC}$ & $64 \%$ & $82 \%$ & $63 \%$ & $25 \%$ & NA & $69 \%$ \\
\hline & \multirow{4}{*}{$\begin{array}{l}\text { Annual minimum } \\
\text { production }\end{array}$} & $C$ & 7 & 10 & 9 & 0 & 0 & 26 \\
\hline & & $N C$ & 8 & 18 & 10 & 0 & 0 & 36 \\
\hline & & NA & 1 & 0 & 0 & 3 & 5 & 10 \\
\hline & & $\% \mathrm{NC}$ & $53 \%$ & $64 \%$ & $53 \%$ & $0 \%$ & $0 \%$ & $58 \%$ \\
\hline \multirow{8}{*}{ 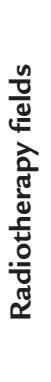 } & \multirow{4}{*}{$\begin{array}{l}\text { Structure and } \\
\text { available services }\end{array}$} & $\mathrm{N}$ & 6 & 0 & 18 & 1 & 0 & 25 \\
\hline & & $N C$ & 8 & 0 & 1 & 0 & 0 & 9 \\
\hline & & NA & 0 & 28 & 0 & 3 & 5 & 36 \\
\hline & & $\% \mathrm{NC}$ & $57 \%$ & NA & $5 \%$ & $0 \%$ & NA & $26 \%$ \\
\hline & \multirow{4}{*}{$\begin{array}{l}\text { Annual minimum } \\
\text { production }\end{array}$} & $C$ & 4 & 0 & 1 & 0 & 0 & 5 \\
\hline & & NC & 12 & 0 & 18 & 1 & 0 & 31 \\
\hline & & NA & 0 & 28 & 0 & 3 & 5 & 36 \\
\hline & & $\% \mathrm{NC}$ & $75 \%$ & NA & $95 \%$ & $100 \%$ & NA & $86 \%$ \\
\hline
\end{tabular}

Source: Installed Capacity Form of the RHCCC 2013, Ordinance SAS/MS No. 140 - 2014 and Datasus, 2013.

Regarding the minimum production of surgeries expected, the analysis excluded the five exclusive pediatric cancer care establishments because they did not meet the criterion of 650 surgeries/year. Of the remaining 67 establishments, only nine produced the minimum number of surgeries required by the Ordinance, yielding an $87 \%$ rate of nonconformity.

In all, the expectation of surgical procedures for the year 2014 was 75,400, with 49,360 being performed, representing $69 \%$ of the expected. In terms of the number of surgeries, the median outstanding balance of surgeries was 388, ranging between 2,282 less surgeries and 2,043 more. Regarding the percentage of surgeries performed versus the minimum target, the median was $49 \%$, varying from 1 to $298 \%$.

Among the nine establishments that met the target (conforming), all of them performed more procedures than expected, with a median of 337 procedures, ranging from 17 to 2,043 in terms of the number of surgeries. The worst establishment in the group did 3\% above the target and the best did 98\%. In the group of 58 establishments that did not meet the goal (nonconforming), the median number of procedures was 429 , ranging from 34 to 2,282 surgeries and, in percentage terms, from 1 to $99 \%$. This group included the five general hospitals with cancer surgery that also presented nonconformity in the structure and services available, that is, no connection to a UNACON or CACON and lack of a surgical cancer team. In one of these hospitals, there were no gynecologists and no mastologists; in another, there were no general surgeons; and, in a third one, no general surgeons and no urologists. In all of these cases, the target was 650 surgeries per year and the median nonconformity was 423 less surgeries. 
Only seven (10.5\%) of the 67 establishments analyzed showed conformity in the two items analyzed: structure and services available and minimum surgical production.

\section{Chemotherapy}

For the conformity analysis according to the structure and provision of services for clinical oncology, the five general hospitals with cancer surgery and the two hospitals that did not return the form were excluded. Therefore, $69 \%$ of the 65 establishments analyzed were classified as nonconforming.

The reasons for nonconformity in the authorization were the lack of palliative care and pain management in 38 establishments, followed by a lack of hemotherapy services available 24 hours in five establishments. The other reasons appeared in a lower frequency, however, we can highlight the lack of medical residency programs in surgical oncology in seven establishments, of radiotherapy in five and of clinical oncology in three. In four establishments there was no chemotherapy center in the hospital structure, and one of them did not report whether apheresis and platelet transfusion were available. We can also highlight three establishments that, though not qualified for hematologic-oncology, reported having a team in this specialty.

For the classification of conformity according to the minimum production, ten establishments were excluded, namely the five general hospitals with cancer surgeries and the five with exclusive pediatric cancer care. Therefore, 36 of the 62 establishments (58\%) that would have to comply with the number of chemotherapy sessions recommended by the Ordinance were nonconforming. Despite this, the overall production of chemotherapy sessions in the State in 2013 surpassed the estimated number by $23 \%$.

For the 35 establishments classified as nonconforming, the estimated target for chemotherapy sessions per year ranged from 5,300 to 26,500. The median was 5,300. With respect to the production of chemotherapy sessions, the median was 4,162, and the difference between the actual and estimated figures was 3,595 sessions per establishment per year.

In the 27 establishments classified as conforming, the target ranged from 5,300 to 47,700, with a median of 5,300 . The median production here was 14,001 . In relation to the percentage of the target met, the variation was 101 to $879 \%$ and the median difference in the number of sessions was 8,034 , ranging from 27 to 41,284 more chemotherapy sessions per year per establishment.

\section{Radiotherapy}

Thirty-four (34) of the 70 institutions analyzed had radiotherapy services. Nine establishments (26\%) of these were classified as nonconforming. One of them did not present simulation system information, one did not present a brachytherapy service and in the other seven, the reason was the lack of one photon and electron device.

To classify conformity in terms of field production equipment per year, $86 \%$ of the 34 establishments with radiotherapy were classified as nonconforming, totaling 31 establishments.

For the total of 3,870,000 estimated fields for the State, 2,540,717 were performed, representing $65 \%$ conformity with the target.

In the 31 establishments classified as nonconforming, the median estimated fields per equipment per year was 86,000 and the estimated production was 36,353 , ranging from 11 to $98 \%$ of that produced in relation to the estimate. In the five establishments classified as conforming, the estimated median production was 86,000 per hospital per year and production was 136,686 , ranging from a difference of more than 2 to $127 \%$. This group consisted of four CACONs and one UNACON.

Regarding the total production of radiotherapy fields in the state, seven hospitals accounted for $50 \%$, five of which were CACONs and two UNACONs (one of them exclusively for pediatric cancer care). Three of the establishments in this group presented nonconformity in the structure and services available because they are CACONs and do not have a photon and electron device.

Except for the 36 establishments that do not provide radiotherapy services, only one (3\%) of the 34 establishments analyzed showed conformity in the two items analyzed: structure and services available and minimum production of radiotherapy procedures per year.

\section{Discussion}

It is possible to observe a progressive orientation from the model of authorization for oncology adopted by the Ministry of Health to comprehensive and integrated care of cancer patients, from the definition of the line of care to the requirement for the referral of a regional plan, including the closure of sole chemotherapy and radiotherapy services. Comprehensive and integrated care for the cancer patient defines the outcome, reduces mortality and the costs of care. ${ }^{16}$ As such, the hospital can offer all the structure and services needed to cover every step of the line of care or focus on what requires more complex technologies, establishing flows with other levels of care. 
The oncology network enabled in the state of São Paulo in 2013 was concentrated in general hospitals of larger size (large and special sized) and with teaching activities, which can be explained by the fact that these services are highly complex. ${ }^{17}$ Only 12 hospitals in this group were specialized in oncology, and an essential tool in ensuring continuity of care, which is the patient's electronic record, was present in only $38 \%$ of the hospitals in the network, impairing one of the premises of the model of integrated health care organizations, which require information to be accessible to the whole chain of care. ${ }^{4}$

The variation in the proportion of hospitals per inhabitant in the different regions of the state and the lack of qualified hospitals in two RRAS may indicate a volume of patient displacement in search of treatment, a fact demonstrated by the FOSP in the RRAS Reports $2014 .^{18}$ However, the rationale for these displacements was not necessarily based on the number of inhabitants and services offered, since the two RRAS that most referred patients to other regions in proportion to the estimated number of new cases, 12 and 10, have qualified services in the proportion of one to 555,645 inhabitants and one to 269,373 inhabitants, respectively. RRAS 12 mainly refers to RRAS 13, the second region to receive patients in proportion to the number of new cases, and RRAS 9, the first, receives from RRAS 10, 8 and 13. It is in RRAS 9 and 13 that the two hospitals specializing in oncology for adults and children are located.

For chemotherapy, the two main reasons for nonconformity with available structure and services were the lack of palliative care teams in UNACONs and the absence of medical residency programs in the three areas of oncology (surgical, clinical and radiotherapy) in the CACONs. These are reasons that may affect the comprehensive care of patients and the future of the specialty, but do not directly impact the production in sessions. In radiotherapy, most (74\%) of the hospitals were in conformity with the structure, with the main reason for nonconformity relating to technological updates.

There was a wide variation in productivity in the hospitals. In chemotherapy, the median difference between the expected and actual production was 3,595 less sessions in nonconforming hospitals and 8,034 more sessions in conforming hospitals. For radiotherapy, nonconforming hospitals performed 11 to $98 \%$ of that expected in fields and, in the five conforming hospitals, production ranged from 2 to $127 \%$. The four hospitals that presented the highest production in the two modalities are located in the RRAS that receive the most patients from other regions, namely 6,9 and 13 . These were responsible for $15 \%$ of chemotherapy production and $36.5 \%$ of radiotherapy production in the state.

This variation in production among hospitals may lead to a perception of scarcity of available resources, with wait being recorded on the one side while services are available on the other. One aspect that could explain this distortion is the system's funding mechanism and the payment and remuneration method of the hospitals by SUS. In the absence of a regulatory system, supply establishes demand. ${ }^{19}$ The sector is organized with mechanisms to receive patients to perform procedures that are better remunerated by hospitals directly dependent on SUS billing, while at the same time there are referrals to public hospitals at times of treatment that require greater use of resources and remuneration that does not meet with costs. These hospitals have complementary budget allocations that promote a certain sustainability in the operation, but at the same time are often the patient's last choice. Applied to the cancer network of the state of São Paulo, considering that the three modalities of cancer treatment in the SUS are under the system of remuneration of medium and high complexity and almost half of the hospitals are private and under municipal management, the limit of the financial ceiling in the municipalities could contribute to lower-than-expected production.

Another factor that could justify directing the demand to specialized hospitals that present high volumes of care is the perception of users regarding excellence in high complexity services in the SUS. ${ }^{20}$ In this context, hospitals may be attracting the demand of other regions and even other states in the federation, probably dodging the formal transfer mechanisms. It is known that the Southeast region receives the highest amount of patient from other regions ${ }^{21}$ and that high complexity procedures in the SUS, specifically chemotherapy and radiotherapy, have increased at a greater proportion that the population in the Southeast region. ${ }^{19}$

Despite the urgent need to qualify more hospitals in the state under the estimated parameters of new cases given by the Inca, when analyzing the treatment modalities, there would still be an available structure with less than expected production. Faced with this data, we can say that the installed network structure was sufficient to meet the demand, but showed variations of production between services, with a concentration of production in a few units. Thus, there is a need to direct the discussion and actions towards the acquisition of tools and management structures, with a focus on reducing the suffering of patients, who end up undergoing a routine of daily trips to chemotherapy and radiotherapy sessions, or need 
to change their routines by moving to another city while they are undergoing treatment.

Thus, the São Paulo State Health Department has adopted the strategy of inviting representatives of the specialty, that is, reference oncologists representing hospitals qualified by the SUS with greater production, and has established a system of governance with technical-scientific forums and SES executive support, including the participation of the FOSP and with its main base in the Icesp, an institution that has become a benchmark for the state due to its management model and connection with the University of São Paulo Medical School. The State took the lead in organizing a thematic network and specialists were able to contribute to the definition of public policies. Under the scope of the Committee, projects for the structuring and implementation of the Oncology Regulation Center, the Regulation of Acute Leukemia, the Information Platform for Oncology Patients, the preparation of Manuals, Protocols and Training Programs and Training of Network professionals were presented, and an annual forum of scientific meetings to discuss oncology in the reality of the SUS, the Paulista Oncology Symposium, was created. As such, hospitals were able contribute to the development of clinic management technologies and substitution processes.

The use of a regulation center to promote equity, accessibility and integrality of assistance could secondarily provide knowledge of the demand and use of services and, consequently, allow for the elaboration of parameters for planning the structure of the installed network itself. ${ }^{22}$ The parameters currently available in Brazil and the state of São Paulo still present inconsistencies. However, they are the basis for evaluation in the official processes for authorizing services in the SUS.

\section{Conclusion}

The network was evaluated from the perspective of maintaining excellence based on the qualification criteria required by the Ministry of Health, which provides the minimum structure and services available and the minimum production volume of cancer surgeries, chemotherapy sessions and radiotherapy fields. In relation to the structure and services available, $80 \%$ of the hospitals showed conformity for cancer surgeries, $31 \%$ for chemotherapy and $74 \%$ for radiotherapy. The most frequent items of nonconformity for chemotherapy were the absence of palliative care services and, for radiotherapy, the lack of one piece of photon and electron accelerator equipment. Regarding minimum production, only $13 \%$ of hospitals showed conformity regarding cancer surgeries, $42 \%$ regarding chemotherapy and 14\% regarding radiotherapy.

The installed network was of sufficient structure and size to meet the demand for new cancer cases, but there were regional differences and a wide variation of productivity between services, which probably impacted on patients' access, and promoted patient wait at the same time when there were idle services in the facilities. The resources used in the oncology network would be better used with the adoption of management tools, such as case regulation, which would assist in the distribution of cases according to demand, installed competencies and the availability of services.

\section{Resumo}

Rede de atenção oncológica: análise da estrutura de serviços habilitados

Introdução: $\mathrm{O}$ câncer chegou à agenda dos gestores de saúde, provocando-os a pensar em novos modelos de organização do sistema.

Objetivo: Estudo da rede oncológica do Sistema Único de Saúde no estado de São Paulo por meio da análise da estrutura da rede instalada e habilitada para tratamento e suas características quanto ao perfil e à distribuição dos estabelecimentos, estrutura e serviços disponíveis e produção mínima anual para a manutenção da excelência.

Método: Estudo de caso único e integrado, utilizando dados secundários do Datasus, Inca, RHC e CNES e dados primários de documentos oficiais do Comitê de Referência em Oncologia do Estado de São Paulo. Como parâmetros de referência, a Portaria SAS/MS n. 140 de 2014. Resultados: Em abril de 2013 estavam habilitados 72 estabelecimentos para atendimento de oncologia no SUS. Pelo critério populacional, o estado possuía um serviço habilitado para cada 581.961 habitantes, distribuídos de forma desigual pelas 17 RRAS. Com relação à estrutura e aos serviços disponíveis, $80 \%$ dos hospitais estavam em conformidade para cirurgias oncológicas, $31 \%$ para quimioterapia e $74 \%$ para radioterapia. Em relação à produção mínima, $13 \%$ dos hospitais estavam conformes em cirurgias oncológicas, $42 \%$ em quimioterapia e $14 \%$ em radioterapia. Conclusão: A rede instalada apresentava estrutura e tamanho suficiente para atender à demanda de casos novos de câncer, porém havia diferenças regionais e ampla variação de produção entre os serviços, o que provavelmente impactava no acesso dos pacientes, promovia a criação de filas de espera ao mesmo tempo que havia serviços com ociosidade nas instalações. 
Palavras-chave: oncologia, serviços de saúde, políticas, planejamento e administração em saúde.

\section{References}

1. Organização Mundial da Saúde (OMS). Cuidados inovadores para condições crônicas: componentes estruturais de ação: relatório mundial. Brasília; 2003.

2. Gröne O, Garcia-Barbero M; WHO European Office for Integrated Health Care Services. Integrated care: a position paper of the WHO European Office for Integrated Health Care Services. Int J Integr Care. 2001; 1:e21.

3. Wagner EH. Chronic disease managment: what will take to improve care for chronic illness? Eff Clin Pract. 1998; 1(1):2-4.

4. Shortell SM, Gillies RR, Anderson DA, Mitchell JB, Morgan KL. Creating organized delivery systems: the barriers and facilitators. Hosp Health Serv Adm. 1993; 38(4):447-66.

5. Viana ALA, Albuquerque MV. Perspectivas de regiões e redes na política de saúde brasileira. Saúde Debate. 2015; 39(n especial):28-38.

6. Mendes EV. As redes de atenção à saúde. 2. ed. Brasília: Organização PanAmericana da Saúde, Organização Mundial da Saúde, Conselho Nacional de Secretários de Saúde; 2011.

7. São Paulo (Estado). Secretária de Estado da Saúde. Deliberação CIB n. 36 de 21 de setembro de 2011. São Paulo, 2011.

8. Tamelini RM. O câncer no Estado de São Paulo: uma análise da morbi mortalidade e do gasto público [dissertation]. São Paulo: Faculdade de Ciências Médicas da Santa Casa de São Paulo; 2008.

9. Teixeira JMC, Portas SLC, Valim S, Mendes JDV, Rodrigues EL. Plano Estadual de Saúde do Estado de São Paulo 2012-2015. São Paulo: Secretaria de Estado da Saúde; 2012

10. Koyama MF. O caso do ICESP. Debates GV Saúde (São Paulo). 2010; (9):18-21.
11. Hoff PMG, Estevez Diz MDP, Pereira J, editors. Manual de condutas em oncologia. 2. ed. São Paulo: Atheneu; 2013.

12. São Paulo (Estado). Secretaria de Estado da Saúde. Resolução SS n. 15 de 14 de fevereiro de 2012. São Paulo; 2012.

13. Correa MCMMA, Naffah Filho M, Cecilio MAM, Tamelini RM. Saúde em dados contextualização: diretrizes para a atenção oncológica no Estado de São Paulo: contribuições para o debate. BEPA. 2011; 8(92):24-43.

14. Brasil. Ministério da Saúde. Secretaria de Atenção à Saúde. Departamento de Regulação, Avaliação e Controle. Coordenação Geral de Sistemas de Informação. Manual de bases técnicas da oncologia - SAI/SUS - Sistema de informações ambulatoriais. 19. ed. Brasília; 2015.

15. Brasil. Ministério da Saúde. Portaria SAS n. 140 de 27 de fevereiro de 2014. Brasília; 2014.

16. UICC/ICESP. Curso básico sobre câncer da UICC. Trad. Roger Chammas [cited $2015 \mathrm{Jul}$ 20]. Available from: http://www.icesp.org.br/Sala-de-ImprensaEnsino-e-Pesquisa/Educacao/UICC---Curso-basico-sobre-Cancer.

17. Bittar OJN, Mendes JDV, Magalhães A. Rede hospitalar no estado de São Paulo: mapear para regular. São Paulo: SES/SP, 2011.

18. Fundação Oncocentro de São Paulo (FOSP). Caracterização da assistência oncológica nas Redes Regionais de Atenção à Saúde no estado de São Paulo. Março, 2014. Available from: www.fosp.saude.sp.gov.br/publicacao/ boletinsraas

19. Porto SM, Santos IS, Ugá MAD. A utilização de serviços de saúde por sistema de financiamento. Ciênc Saúde Coletiva. 2006; 11(4):895-910.

20. Vianna SM (coordinator). Atenção de alta complexidade no SUS: desigualdades no acesso e no financiamento. Volume I. Ministério da Saúde - SCTIE/DES e IPEA - DISOC. Brasília, DF, 2005.

21. Gadelha MIP. Planejamento da assistência oncológica: um exercício de estimativas. Rev Bras Cancerol. 2002; 48(4):533-43.

22. Vilarins GCM, Shimizu HE, Gutierrez MMU. A regulação em saúde: aspectos conceituais e operacionais. Saúde Debate. 2012; 36(95):640-7. 